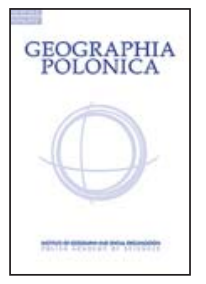

\title{
IMPACT OF DISPERSED SETTLEMENT ON THE STRUCTURE AND DIVERSITY OF RURAL LANDSCAPE (CASE STUDY OF VILLAGE HRUŠOV, SLOVAK REPUBLIC)
}

\author{
Ján Hanušin \\ Institute of Geography \\ Slovak Academy of Sciences \\ Štefánikova 49, 81473 Bratislava: Slovak Republic \\ e-mail: hanusin@savba.sk
}

\begin{abstract}
The impact of a dispersed settlement on the changes of the land cover (LC) and landscape diversity (LDI) in the years 1950, 1986 and 2016 was analyzed on four spatially different levels: on the level of the whole cadastral area, 60 circular areas - hinterlands of hamlets, 15 circular areas in agricultural land outside hamlets and areas outside circular areas. The primary hypothesis that the landscape with a dispersed settlement is internally differentiated in terms of LC and LDI changes and that a dispersed settlement itself is an important driving force of these changes has been confirmed.
\end{abstract}

\section{Key words}

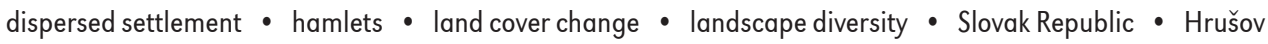

\section{Introduction}

Despite the ever-continuing concentration of population in compact (clustered) settlements, dispersed (scattered) settlements are still present in various forms in most of the world. A traditional dispersed settlement with its residential and landscape structure, distinctive building culture, and social and cultural peculiarities have created unique manifestations of material and spiritual heritage and genius loci. Even more than half a century apart, we can partly agree with Birch (1967) that, despite its expansion, dispersed settlements are paid much less attention in scientific literature than the study of compact settlements. Unlike dispersed settlement in the rural areas, discussed in our study, the studies dealing with the dispersed settlement in the urban hinterland, resulting from the urban sprawl, are more numerous (e.g. Salvati et al., 2012; Urbieta et al., 2019; Śleszyński et al., 2020).

The definition of the dispersed settlement can vary from country to country. As Schwartz (1989) pointed out, there is no generally accepted definition of the term dispersed settlement which is conditioned, 
among other, by differences in the historical, social and cultural development of individual regions and, of course, differences in the natural environment. Mandal (1988) provides an overview of attempts to define precisely the areas of dispersed settlement, mostly based on data of the number of dwellings in the settlement, the share of cultivated area, settlements in the region (concentration index, Bernhard 1931; Pawlowski 1938; dispersion rate, Demangeon 1933; settlement continuity rate, Stone 1962). Amate et al. (2016) define dispersed settlement as a settlement area outside the core of the settlement that has no administrative and legal entity, and which consists of one or a group of inhabited houses. Kiełczewska-Zaleska (1970) includes all farms lying more than $150 \mathrm{~m}$ from a compact or loosely-clustered village and all farms in the village with an entirely dispersed layout in disperseed settlements in Poland. Small clusters, hamlets up to five residential houses were included in dispersed housing estates (Kiełczewska-Zaleska, 1970). In a study in Flanders, Belgium, Van De Velde et al., (2010) defined dispersed settlement as an area with a minimum distance of 150 meters between buildings. According to Roberts (1996), 150 meters from a compact settlement is the distance at which a farmstead can be considered a separate settlement unit. Omasta (2010) defines a dispersed settlement in Myjava in western Slovakia as such, in which there is the presence of at least one settlement located outside the core settlement of a territorial unit (usually a municipality) distant from it at least $200 \mathrm{~m}$ and at the same time these settlements must form a larger unit, i.e. they cannot occur in the territory singly.

The example of dispersion rate propose Roberts and Wrathmell (2000) who studied the density of English rural settlement and set the Dispersion hamlet score based on the density of hamlets per $10 \mathrm{~km}^{2}$.

The regional names of dispersed settlement forms in Slovakia do not reflect their size or morphological characteristics (kopanice, lazy, štále - Verešík, 1974). Although the terminology is not consistent even between the UK and the USA, the individual hierarchical levels of dispersed settlement are sometimes more precisely distinguished there (see e.g. isolated farmsteads, hamlets and scattered dwellings, Bibby \& Brindley, 2013). Therefore, it was important to choose the English equivalent for the Slovak term laz used in the studied region, which refers to an isolated group of houses representing the basic unit of the dispersed settlement system. As the closest term to the Slovak term laz, we chose the term hamlet in the sense of Roberts (1996), which is defined as a settlement unit of 3-8 farmsteads located 250 m apart from each other, which best corresponds to the settlement pattern of the study area, while recognizing the differences arising from different historical, cultural-economic and physical-geographical environment.

The majority of the dispersed settlements still existing in the Slovak Carpathians owe their origin to several settling waves that took place between the 16th and 19th centuries (Hromádka, 1943; Verešík, 1974; Horváth, 1980). Huba states that a dispersed settlement only meant relocation of a part of population in remote and unsuitable segments of the cadastre while to some extent it always represented an extreme and emergency settlement pattern (Huba, 1989). In spite, dispersed settlements across Slovakia cannot be perceived as a marginal phenomenon. Municipalities in this form of settlement occupy $4640 \mathrm{~km}^{2}$, i.e. about $10 \%$ of the overall area of Slovakia (Verešík, 1974). This author identified 166 villages with dispersed settlements in 1961 where about 140,000 people $(3.3 \%$ of the total population) lived in approximately 2900 hamlets. For comparison, in Spain almost 12\% of the population lived in dispersed settlements in 1960 while in 1980 it was 7\% (Amate et al., 2016).

Dispersed settlements in some form occur in many countries around the world but the studies explicitly addressing this issue are relatively underrepresented. Studies from Japan are known from the 1950s (Matsumoto, 1950, Okamoto, 1955 and Takaki, 1958). 
The theory of localization of farms in the USA Corn Belt, which are de facto one of the types of dispersed settlements, was studied by e.g. Birch (1967) and Hudson (1969). The development of a specific form of dispersed settlement (khutors) in the European part of Russia was studied by Rostankowski (1982). Owen and Sarlov-Herlin (2009) studied dispersed settlements in the UK in terms of sustainability, Lake et al. (2014) studied dispersed farmsteads in Kent, UK. The prevalence of dispersed settlements in an agricultural landscape in Ireland is highlighted by Environmental Protection Agency (2008). Dispersed settlements - tanye - were studied in the Hungarian lowlands by Kovács and Farkas (2011), dispersed and decentralized settlements in Slovenia were analyzed by Černe (2004) and by Hočevar (2012), in the eastern part of the Balkan Peninsula by Frolec (1980), in southern Spain by Amate et al. (2016). Bodzak and Kiełczewska-Zaleska (1973-1977) compiled a map of dispersed settlement in Poland. The position and development of dispersed settlements in the wider context of settlement systems have been studied by e.g. Fletcher (2019) and Troha (2017). Decades ago Dovring (1965) have drawn attention to the link between farm settlements, landscapes and the social structure of the area.

Due to its extension dispersed settlement was studied in Slovakia already in the first half of the last century by Martinka (1927), Janšák (1929), Deffontaines (1931), Hromádka (1943), Fekete (1947). Later on, the issue of dispersed settlements was studied by Mésároš (1966), Verešík (1974), Horváth (1980), Lukniš (1980), Lauko (1985), Huba (1989, 1990, 1997), Spišiak (1998), Petrovič (2006a,b), Omasta $(2010,2011)$. The phenomenon of the dispersed settlement in Hrušov (Fig. 1) is relatively widely studied, e.g. Botík (1980), Švecová (1984, 1988), Zrníková and Hrčková (2012), Brada et al. (2014), Hanušin and Lacika (2017, 2018).

Based on the research conducted so far in the studied area and the results of relevant research in other areas with dispersed settlements, we defined the following hypotheses presumed for the study area:

- the landscape with a dispersed settlement is internally diversified in terms of the nature of land cover (LC) and landscape diversity (LDI) and their changes;

- hinterlands of hamlets have undergone the most significant changes of LC and LDI compared to other areas;- the share of arable land and forests in the hinterlands of hamlets depend on the distance from the core part of the municipality and the selected morphometric parameters (average slope and average altitude a.s.l.);

- population number in hamlets determines the LDI changes in hinterlands of hamlets.

\section{Material and methods}

The basic methodical procedure is to evaluate LC and LDI changes at four levels which partly overlap:

- whole cadastre area (2331 hectares) (WA);

- 60 circular areas around hamlets (741 ha in total), hinterlands of hamlets $(\mathrm{HH})$;

- area outside the hinterlands of hamlets (1590 ha), remaining area (RA);

- 15 circular areas in a predominantly agricultural landscape without hamlets (187 ha in total), agricultural landscape hinterland (ALH).

$\mathrm{HH}$ and $\mathrm{ALH}$ levels allow correct comparison of the effect of hamlets on LC and LDI in the circular areas of equal size (Fig. 2). In addition to the absence of hamlets, on the $\mathrm{ALH}$ level there is a reduced forest area. The LC and demographic data from the years 1950, 1986 (1990 for demographic data) and 2016 were processed and analyzed, however, not all of them were applied to all four levels. The period between the years 1950-1986 (1990) is referred to as the 1 st period and the period between 1986 (1990)-2016 is the 2nd period. Settlement pattern of the study area consists of the core part (densely built-up area of the original settlement) and the network of hamlets spread over the rest of the cadastre. The smallest map unit corresponds 
to an area of approximately 450-500 $\mathrm{m}^{2}$. The observed time horizons express the state of $L C$ in the pre-collectivization period (1950), in the period of advanced collectivization (1986) and in the recent post collectivization period (2016). Georeferenced sheets of the historical orthophoto aerial images of Slovakia (Historická ortofotomapa, 2017) were used as the basic database for the year 1950. Aerial images from 1986 were georeferenced to the S-JTSK coordinate system. The database for the preparation of the LC map for the year 2016 consisted of the relevant sheets of the aerial orthophotomap from 2003 updated based on the Google Earth map server (Google Earth Pro 2016). For simplification we evaluated only 6 LC types: arable lands, permanent grasslands (referred to as grasslands), forests and non-forest woody vegetation (referred to as forests), built-up areas in hamlets including adjoining gardens (referred to as hamlets), agricultural mosaics and areas with succession (referred to as succession areas). The main types cover more than $95 \%$ of the area in all periods under review. In correlation analysis only 3 main LC types were evaluated (forests, arable land, grassland).

To distinguish between two most distinct local land use types (agricultural - forest) the index of agricultural utilization (IAU index) was calculated:

$$
I A U=\frac{\left.\sum \text { (arable lands }+ \text { grasslands }\right)}{\sum(\text { forests }+ \text { succession areas })}
$$

(all values are given in \% share of the area concerned).

$\mathrm{HH}$ and $\mathrm{ALH}$ levels were delimited by a circle with the radius of 200 meters $(12.56 \mathrm{ha})$, centred in the relevant hamlet built-up area $(\mathrm{HH})$ or randomly chosen in an agricultural land without hamlets (ALH). Due to the dense network of hamlets, the system of circles generated 17 overlaps (multiple in some cases) at the $\mathrm{HH}$ level. We use the term $\mathrm{HH}$ in the context of 60 circular areas. The general term hamlet(s) is used, which refers to all the hamlets in the study area, when it is more appropriate in the context. When evaluating $\mathrm{LC}$ conversion the conversion tables as defined by Feranec et al. (2002) was followed; the extent of changes was obtained from the pivot table. The correlation coefficient $(r)$, and that of determination $\left(r^{2}\right)$ were used to determine the relationship between the proportion of the area covered by the main LC types and selected parameters (distance from the core part, average slope and average altitude of the centre of the circle) on the $\mathrm{HH}$ and $\mathrm{ALH}$ levels. The LDI has been assessed from LC changes using the Shannon Diversity Index (SHDI) which was calculated for all the three-time horizons at all the assessed levels. The mean patch size, number of patches and number of patches per ha of main LC types at the $\mathrm{HH}$ and ALH levels were also analyzed. Detailed data on the population of each hamlet were obtained from the 1950 census (Národný archív SR), documents for the Territorial Plan of Hrušov (Kolektív, 1990) and from the parish register (Matrika, Hrušov).

\section{Study area and the development of cultural landscape of hamlets}

Most of the cadastre of the village Hrušov (2331 ha) is located in the southern part of central Slovakia (Fig. 1) on the border of the Ipel'ská kotlina (basin) and the Krupinská planina (plain), known as the geomorphological sub-unit Modrokamenské úboče (slopes) (Mazúr \& Lukniš, 1978). The complex of volcanic-sedimentary rocks prevails. Altitudes vary between 200-521 m a.s.l., the plains in the northern part reach an average of 450-490 m a.s.l. The average annual temperature is approximately $8.8^{\circ} \mathrm{C}$, the average annual rainfall is less than $600 \mathrm{~mm}$ (Lapin et al., 2002). Poorly permeable volcanic rocks, lack of rainfall and location on the watersheds cause low groundwater reserves. The soil cover is dominated by Cambisols. Oak forests with Quercus cerris and Carpathian oak - hornbeam forests in higher positions cover the majority of the area (Maglocký, 2002). 


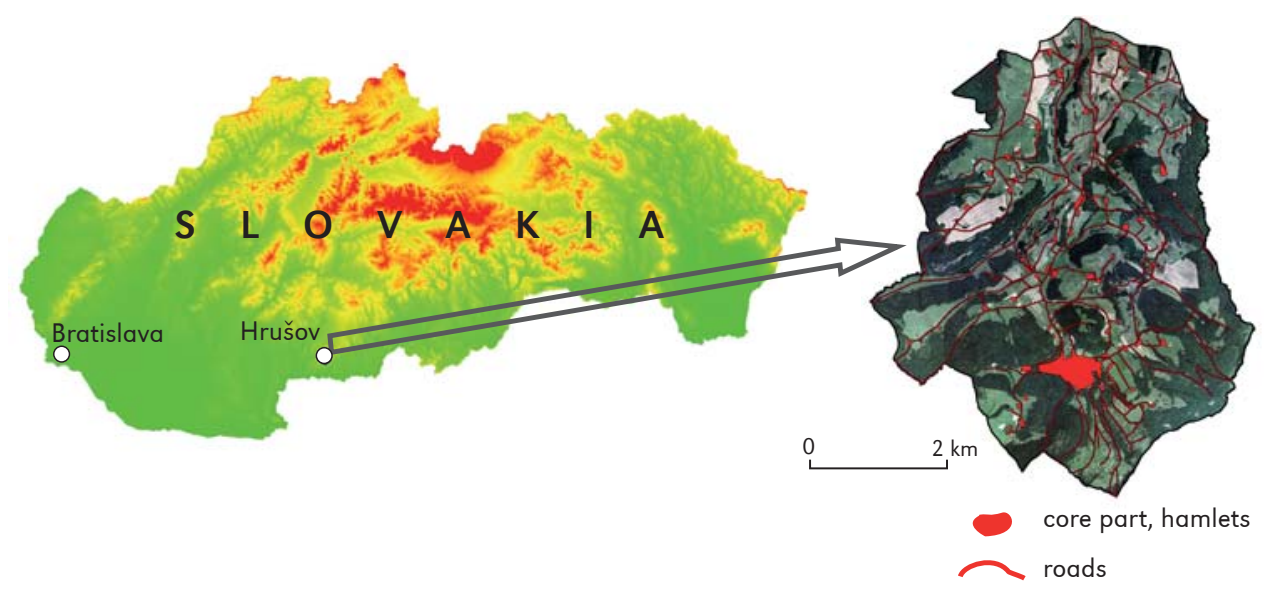

Figure 1. The study area

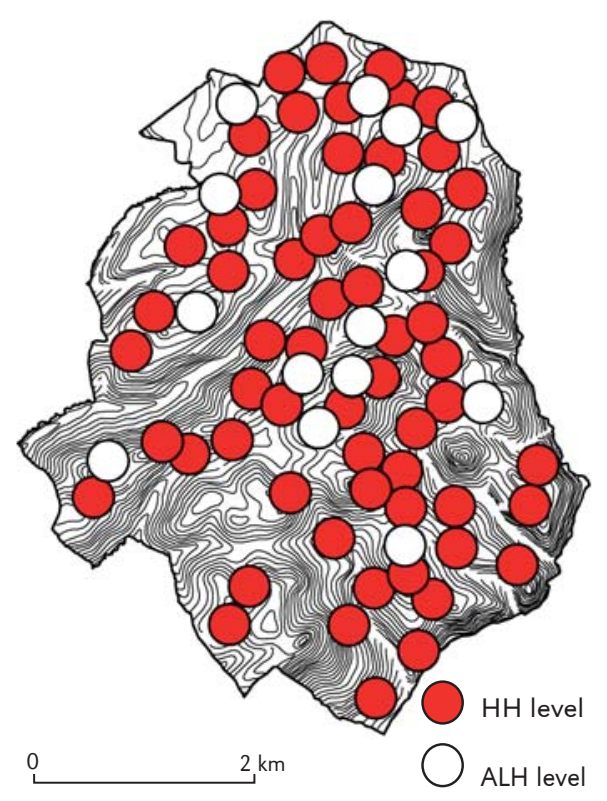

Figure 2. Distribution of $\mathrm{HH}$ and ALH levels

The dispersed settlement in its present form emerged at the end of the 19th century making the dispersed settlement in Hrušov one of the earliest of its kind in Slovakia (Botík, 1980). The hamlets were founded by the locals, unlike most of the surrounding villages where the hamlets were founded by the immigrants from the northern regions (Švecová,
1984). First the hamlets in Hrušov were used as seasonal housing, later on they were transformed into year-round use. Gradually, most of the local people owned two dwellings - one in the core part, another in the hamlet. This so-called double-residency fully developed during the World War I (Brada et al., 2014). The double-residency lasted almost the entire 20th century and undoubtedly affected the way of cultivation techniques and LC structure. Even in 1991, nearly half of the 437 houses in the area were hamlets (Škrdlová, 2015). During the onset of socialism after 1950, unlike most of Slovakia, the process of collectivization of agriculture into cooperative farms did not take place in Hrušov. The character of LC inherited from the interwar period survived with little changes the next decades. Foundation of agriculture cooperative farms in 1979 changed the landscape and the way of life in the village. Hamlets, as protuberant land management points, gradually lost their importance and many of them were later depopulated.

After the end of socialism in 1989, part of land cultivated by agriculture cooperative farms returned to private hands, people continued to move from hamlets to the core part and the total population of the municipality decreased. Part of the houses in hamlets remained abandoned or their function converted to a recreational one. 


\section{Results}

\section{Hamlets and their demographical background}

The basic demographic trend is the overall population decline of the municipality, with the simultaneous population increase in the core part and its significant decline in hamlets (Fig. 3). In 1950, almost two-thirds of the population lived in hamlets, which implies that most of agricultural activities were carried out in the hamlets and their surroundings. The distribution of the hamlets across the cadastre, the system of road network connecting individual hamlets and the position of core part is significantly determined by the morphological characteristics of the area (Hanušin \& Lacika, 2017).

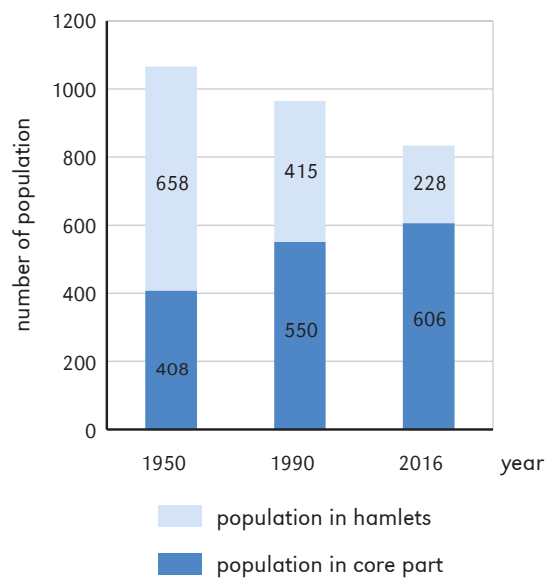

Figure 3. Population in core part and hamlets

There was no significant dependence (measured by $r$ values) between the population in $\mathrm{HH}$ and the distance from the core part, nor was there any correlation between population and morphometric parameters (average altitude a. s. I. and average slope of $\mathrm{HH}$ area), with the exception of the year 1950 when indirect dependence between population and average slope of $\mathrm{HH}$ was recorded (Tab.). This resulted from the concentration of population in hamlets in the northern, less sloping part of the area. In the 2nd period, a kind of centripetal spatial concentration of the population associated with abandonment of the marginal, more distant hamlets can be observed. The average distance of uninhabited hamlets from the core part increased from some $2400 \mathrm{~m}$ in 1990 to $3000 \mathrm{~m}$ in 2016. On the other hand, analogous values for inhabited hamlets dropped from $3000 \mathrm{~m}$ to $2800 \mathrm{~m}$ confirming the trend of depopulation of the marginal hamlets.

\section{LC pattern and its changes}

The general trend in the LC changes is a decrease in the share of arable land and an increase in the share of forests at all levels (Fig. 4). The common features of the distribution of the main LC categories in WA in all observed years were the predominance of forests on the western, eastern and partially southern margins and in the sloping positions in the centre of the area.

A continuous decline of IAU index at all the levels demonstrates the overall decline in agricultural use. In LC conversion - at all levels during both periods, no change areas dominated (Fig. 5). Regarding the higher proportion of no-change areas, the 2 nd period can be considered as more stable compared to the 1st period. The most intensive LC conversions occurred in $\mathrm{HH}$ where only less than $50 \%$ of the area was a no change area. In RA and $\mathrm{ALH}$, there were $56-71 \%$ of no change areas which refers to their relative stability. Afforestation was a dominant conversion at all levels except ALH.

The correlation dependence of the three main LC types at the $\mathrm{HH}$ level and selected characteristics are shown in Table.

The resulting $r$ values at the $\mathrm{HH}$ level point to:

- an increase in the share of forests with a decrease in the share of arable lands and vice versa;

- an increase in the share of forests with an increase in mean slope;

- a decrease of the share of the arable land with an increase in mean slope.

The process of depopulation of hamlets caused that the increase in the share 


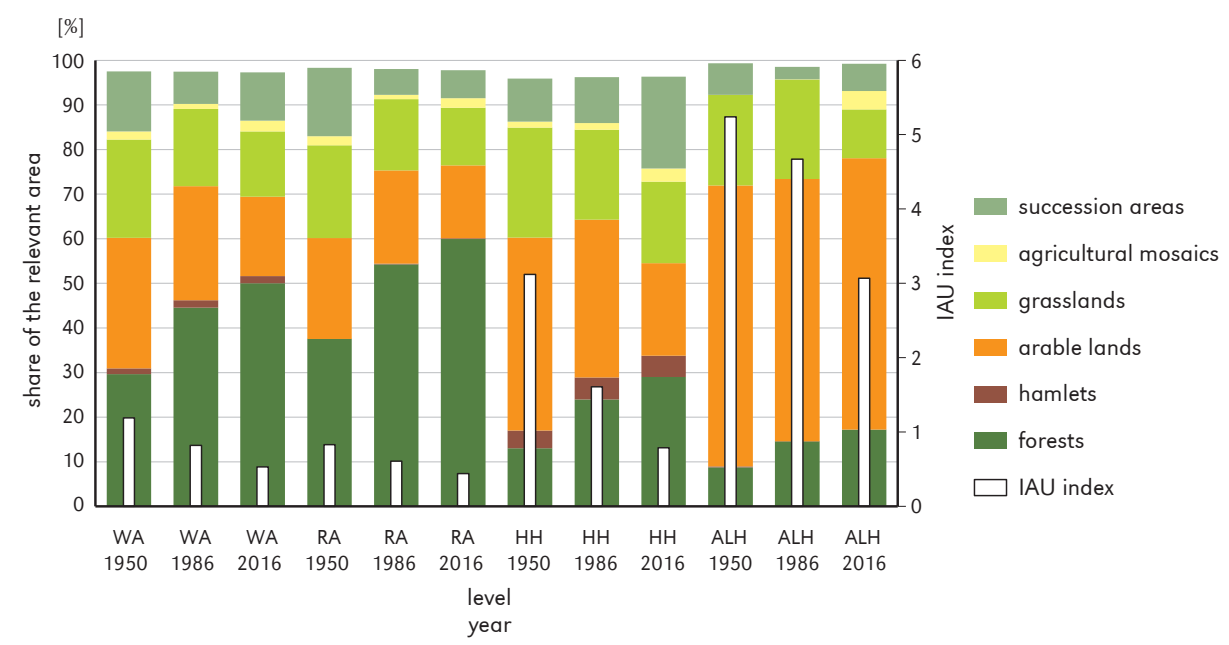

Figure 4. $L C$ in particular levels/years and IAU

Note: the rest to $100 \%$ of the area is covered by less important LC types (roads, dump sites, bare areas, orchards, vineyards, etc.) which are not considered on the graph.

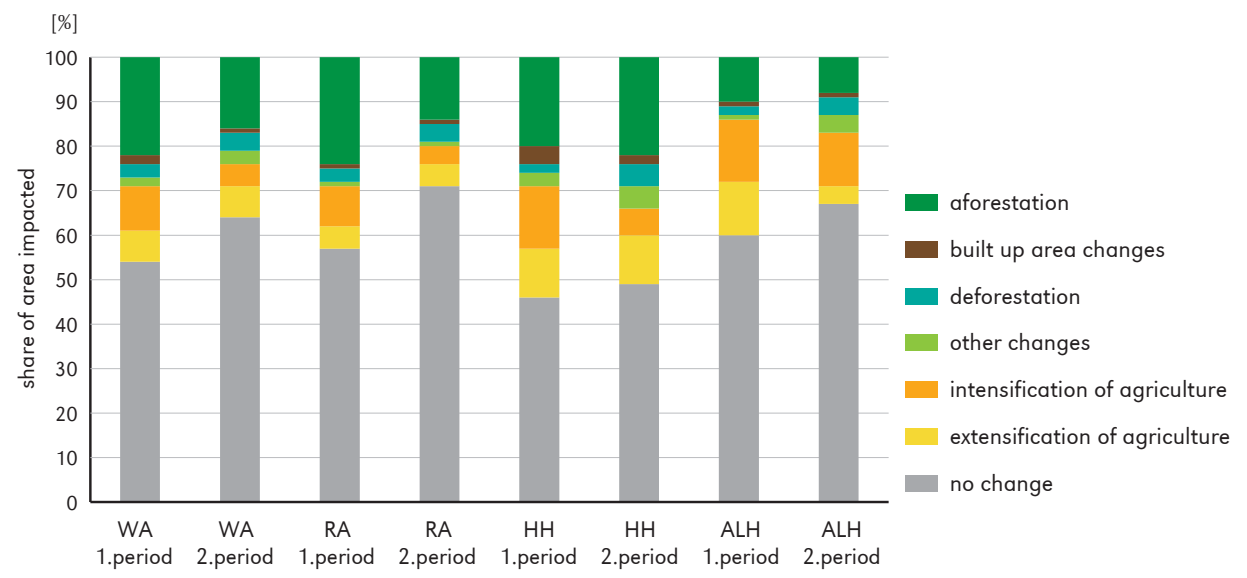

Figure 5. LC conversion at particular levels/periods

of forests and areas with succession and decrease in arable lands at the $\mathrm{HH}$ level is more pronounced comparing to the RA level. Changes were more significant during the 1st period. Different trends were identified at the ALH level where the share of forests also increased but the share of arable lands was the highest and relatively stable of all the levels and years considered. The decrease of intensity of agricultural use measured by IAU index was the least here.

\section{Landscape diversity and its changes}

Changes in LDI over two periods were not of the same nature at each level. During the 1st period at the WA and ALH levels LDI remained virtually unchanged, decreased in RA and increased significantly in $\mathrm{HH}$. During the 2nd period, we identified a decrease in LDI at all the levels except for ALH where it increased. The box-plot graphs (Fig. 6) reveal that LDI values are higher at the $\mathrm{HH}$ level compared to $\mathrm{ALH}$. 
Table. Correlation between basic LC types, main morphometric parameters and population number at the $\mathrm{HH}$ level

\begin{tabular}{|c|c|c|c|c|c|c|c|c|c|}
\hline Share of $L C /$ year & $\begin{array}{l}\text { Distance } \\
\text { from the } \\
\text { core part }\end{array}$ & $\begin{array}{l}\text { mean } \\
\text { slope } \\
\text { Mean } \\
\text { slope }\end{array}$ & $\begin{array}{l}\text { Mean } \\
\text { altitude }\end{array}$ & $\begin{array}{c}\text { Share } \\
\text { of arable } \\
\text { land }\end{array}$ & $\begin{array}{c}\text { Share } \\
\text { of forests }\end{array}$ & $\begin{array}{c}\text { Share } \\
\text { of grass- } \\
\text { lands }\end{array}$ & $\begin{array}{l}\text { SHDI } \\
1950\end{array}$ & $\begin{array}{l}\text { SHDI } \\
1986\end{array}$ & $\begin{array}{l}\text { SHDI } \\
2016\end{array}$ \\
\hline Forests 1950 & -0.387 & 0.338 & - & -0.465 & NA & - & - & NA & NA \\
\hline Forests 1986 & -0.372 & 0.599 & - & -0.600 & NA & - & NA & - & NA \\
\hline Forests 2016 & - & 0.615 & -0.358 & -0.358 & NA & - & NA & NA & -0.482 \\
\hline Arable land 1950 & - & -0.417 & - & NA & -0.465 & -0.351 & - & NA & NA \\
\hline Arable land 1986 & 0.682 & -0.680 & 0.526 & NA & -0.600 & -0.648 & NA & - & NA \\
\hline Arable land 2016 & - & -0.540 & 0.456 & NA & -0.358 & - & NA & NA & - \\
\hline Grasslands 1950 & - & - & - & -0.351 & - & NA & - & NA & NA \\
\hline Grasslands 1986 & - & - & -0.340 & -0.648 & - & NA & NA & - & NA \\
\hline Grasslands 2016 & - & - & - & - & - & NA & NA & NA & - \\
\hline \multicolumn{10}{|c|}{ Numb. of population in hamlet } \\
\hline 1950 & - & -0.375 & - & 0.475 & -0.377 & - & & NA & NA \\
\hline 1986 & - & - & - & - & - & - & NA & 0.561 & NA \\
\hline 2016 & - & - & - & - & - & - & NA & NA & 0.501 \\
\hline
\end{tabular}

Note: Signified correlation value \pm 0,338, (99\% confidence, $n=60$ ) (Pavlík \& Kühnl, 1981). Values in columns - share of arable lands, forests, grasslands refer to share of $L C /$ year in relevant rows.

$(-)$ - correlation below signified value,

(NA) - not applicable value.

A

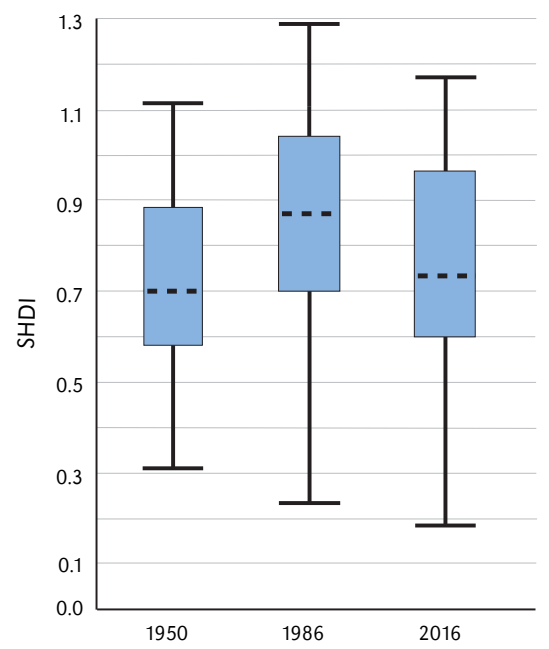

B

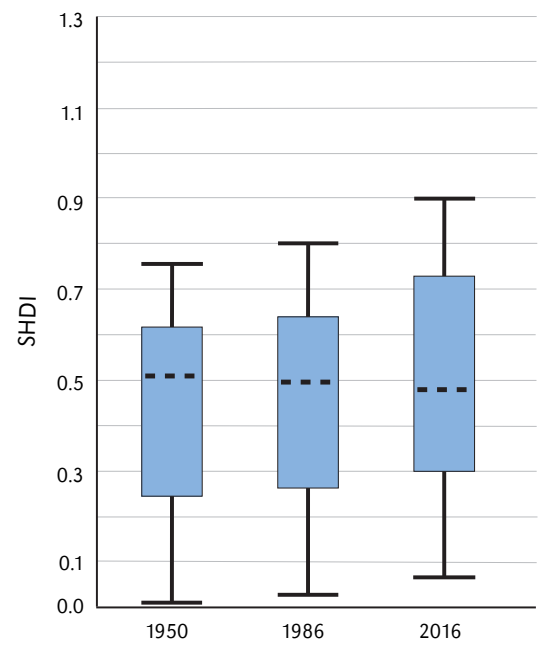

Figure 6. SHDI values at the HH level (A) and at the ALH level (B). 
In 1950, the lowest LDI in $\mathrm{HH}$ was due to the large mean patch size, namely of arable lands, as well as the low number of LC types which caused a lowered LDI compared to subsequent years analysed. This was due to the more populated hamlets and the associated intensive cultivation of $\mathrm{HH}$, relatively less fragmented LC pattern with relatively large arable land blocks and a low share of non-agricultural LC types. Reduction of population and arable land share at the $\mathrm{HH}$ level in 1986, compared to 1950 conditioned extensification of agriculture and afforestation. It was manifested in the structure of $\mathrm{LC}$ by an increase in the patch number per ha (fragmentation) which was reflected in an increase in LDI compared to 1950. During the 2nd period, LDI in $\mathrm{HH}$ slightly decreased again mainly due to a decrease in the patch number per ha and an increase in their mean size in all major LC categories except arable land (Fig. 7). Arable lands were fragmented due to the collapse of the collectivized LC pattern and its conversion primary into grasslands. Mean patch size of forests, grasslands and succession areas in $\mathrm{HH}$ in 1986, compared to 1950, dropped and increased again in 2016.

In terms of the spatial distribution at the $\mathrm{HH}$ level, the highest LDI values in all three years were in the central, and in the years 1986 and 2016 partly also in the northern part of the study area. The lowest LDI values were mainly in 1950 on plains in the north-western part where are the most suitable conditions for cultivation (conditioned by a high proportion of relatively large arable land blocks). The lowest LDI values, mainly in 1986 and 2016, were clustered in in the south-eastern, predominantly forested part which was conditioned by a high proportion of continuous forests (Fig. 8).

The dependence between the population number in hamlets and selected morphometric and LC indicators is different for the year 1950, when most of the population lived in hamlets, and for the years 1986 and 2016 (Tab.). Due to less fragmented LC in $\mathrm{HH}$ in 1950 a low LDI occurred there. $R$ value (between the population number and LDI) was below signified value while in the following years showed a signified value. However, an analysis of the relationship between LDI and population number and number of patches in $\mathrm{HH}$ using a $r^{2}$ value showed that in terms of the LDI changes the number of patches $\left(r^{2}=0.62-0.64\right.$ in three years analysed $)$ is more significant than population number $\left(r^{2}=0.25-0.34\right)$.

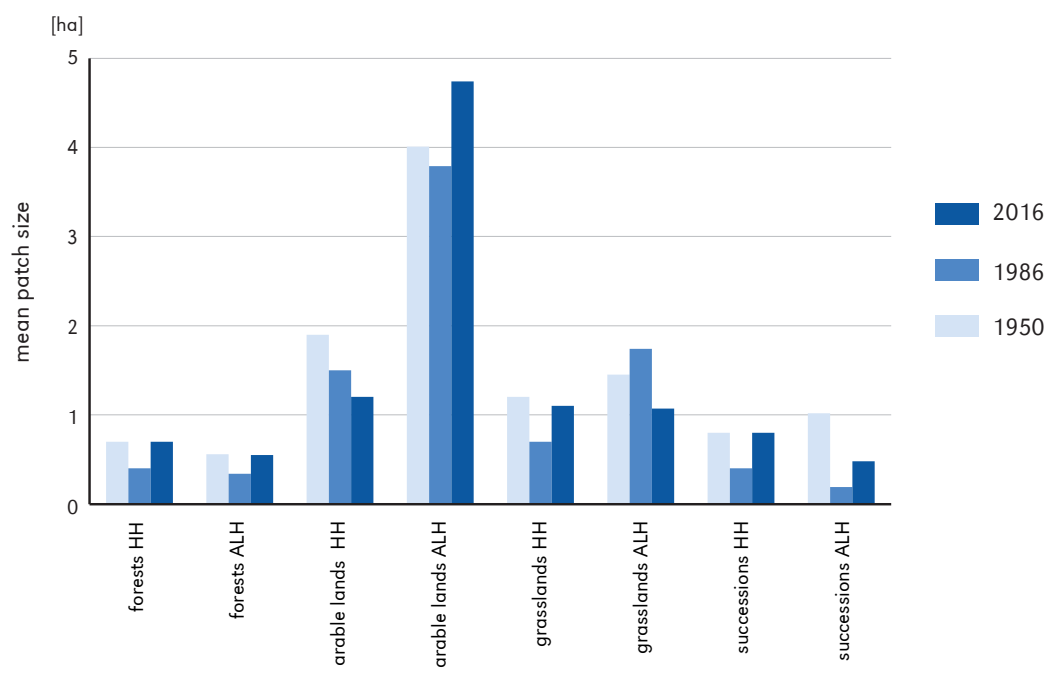

Figure 7. Mean patch size of main LC types at the HH and ALH levels 


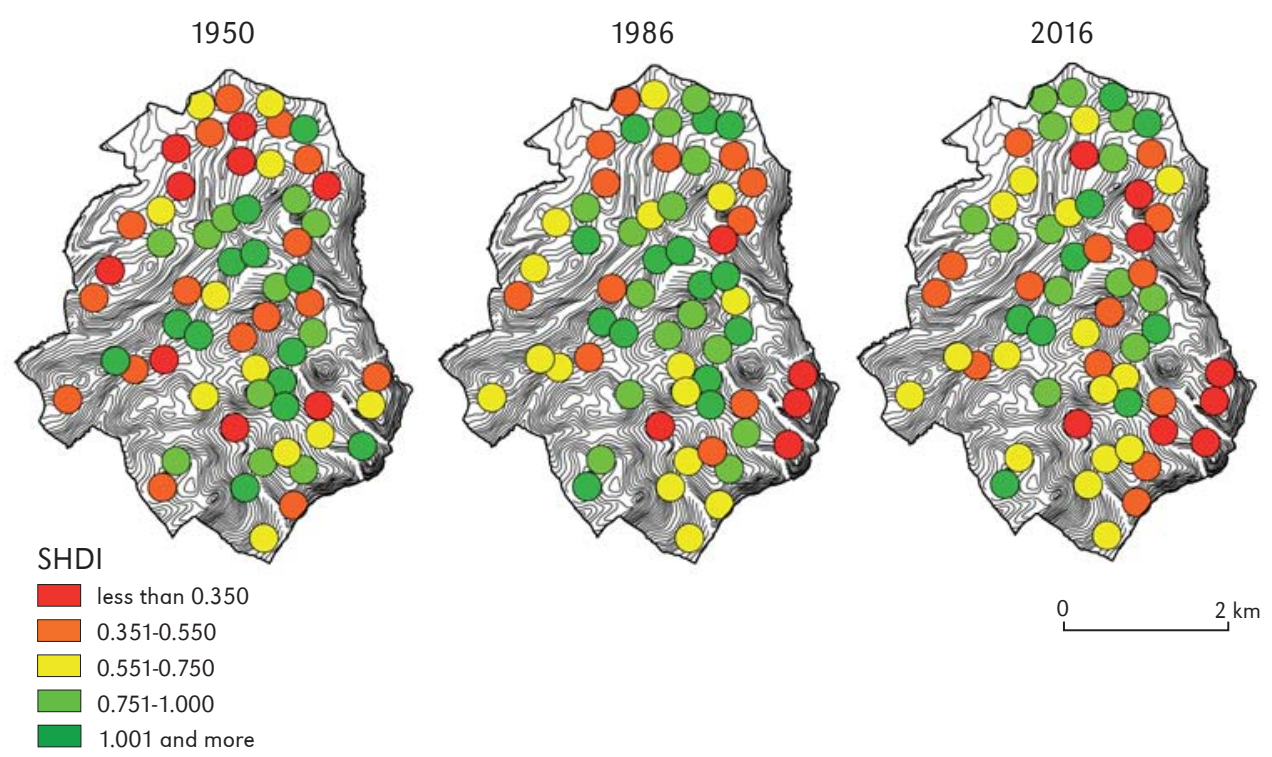

Figure 8. Spatial distribution of the LDI (SHDI value) at the $\mathrm{HH}$ level

\section{Discussion}

The issue of LC and LDI changes in a landscape with a dispersed settlement in a detailed scale has not been broadly studied. In Slovakia only the studies of Petrovič (2006a,b), Zrníková and Hrčková (2012) and Barančok and Barančoková (2016), are worth mentioning. Unlike from the traditional studies which are dealing with the LC and/or LDI changes in one area on several temporal levels, our study compares the LC and LDI changes in one area at several temporal and different spatial levels. A similar approach is the mutual comparison of LC changes in several areas which were presented e.g. on the example of a set of 56 settlements (Skanes \& Bunce, 1997), a military training area and its surroundings (Havlíček et al., 2018) or on the example of three wine-growing areas (Štefunková \& Hanušin 2019). The LC conversion schemes can be unambiguous to a certain extent and their application may result in different results. This topic is highlighted by several authors (Feranec et al., 2010; Rounsevell et al., 2012; Schulp et al., 2019). The IAU index is considered as an ad hoc indicator of agricultural exploitation of the studied area. Coefficients and indexes of the landscape state and changes expressed by $\mathrm{LC}$ are relatively frequent, e.g. coefficient of ecological stability (Míchal, 1982; Miklós, 1986), coefficient of anthropogenic impact on landscape (Kupková, 2001), landscape development intensity index (Brown \& Vivas, 2005), landscape change index (Krajewski, 2015). IAU index is based on the most widespread LC types in the study area. Therefore, its use in areas with different LC structure may be of limited information value.

We chose the 200-meter radius of circles as a compromise between the distance that could be seen as the hinterland for the hamlet and the greater distance at which there would be significant overlapping of circles at a given hamlets density. The circle defined is only a formal boundary. Stone (1991), using an example of the analysis of an archaeological research, states that the distance between the settlement and the cultivated hinterland in an environment with a low level of cultivation technology is not clear. Some other authors, quoted by him, indicate the radius of agricultural activity from 
the settlement between $200 \mathrm{~m}$ - $6 \mathrm{~km}$ (Stone, 1991). Löw and Míchal (2003) state, for a premechanization period of agriculture, the radius of up to 1200 meters for the distance between a house and a field, which is not the case of Hrušov with a dense network of hamlets - the house-field distances here are commonly only tens of meters.

Because of the accessibility, the demographic data and LC data (aerial images) are not always from the identical time. Accession to the 1950 demographic data was most problematic. At that time, several houses in hamlets did not even have a house number, the house numbering having been later changed twice. Therefore, assigning population to the individual hamlets in 1950 was possible only with the help of the local registrar.

During the 1991-2011 period, there was a higher decrease of the population in hamlets (62\%) of Hrušov compared to average 52\% decrease in five surrounding villages with the dispersed settlement in the Krupinská planina (Štatistickýlexikón ..., 2014, own calculations). A double residency model in Hrušov is probably behind this difference. Unlike most of the hamlet villages, where hamlets serve as the exclusive residential place, Hrušov hamlets were not an exclusive residencies for many locals. Thus, a double residency model allowed them flexible migration between their dwellings in the core part and hamlets, if convenient. Similar depopulation model - migration from hamlets to the core part was reported in Montefrio in southern Spain. The number of the population living in a dispersed settlement reached its peak in the 1940s - 1950s when it significantly exceeded the number of the population in the core part, and since then it has been continuously declining (Amate et al., 2016). The opposite trend, i. e. an increase in dispersed housing and with it the number of inhabitants living in dispersed settlements has been recorded in recent decades in Poland (Prus et al., 2017) which is also confirmed by (Gibas \& Heffner, 2018) on the basis of the deepening process of deconcentration and the growing dispersion of buildings in the Polish countryside.
The population number in $\mathrm{HH}$ does not depend on the distance from the core part which is different from the findings reported by Petrovič (2006a) who indicates a dependence between the population in hamlets and the distance from the core part in a hamlet region in west-central Slovakia.

Several authors have identified an increase in the share of forests with altitude and mean slope in the Slovak Carpathians (Šúri, 2003; Druga \& Faltan, 2014). Our results refer to the reverse relation - i.e. decrease in the share of forests and increase in the arable land share accompanied by a rise of mean $\mathrm{HH}$ altitude in the most years considered. The reason is the inverse character of land use in an area with high proportion of flat erosion-denudation relief where a large part of arable lands is located in elevated marginal plains remote from the core part, while large part of forests occupies more sloping positions in lower altitudes, many of them being scattered around the central part. Such landscape configuration together with the dispersed settlement also condition a negative correlation between the distance from the core part and share of forests in the most years considered (with an increasing distance from the core part, the share of forests in 1950 and 1986 decreased and, on the contrary, the share of arable land in 1986 and 2016 increased). This finding is in contrast to the situation in areas without dispersed settlements in the accumulation-erosion relief where the share of arable land is negative and the share of forests is positively correlated with the distance from settlements (Druga \& Faltan, 2014).

It can be assumed that most of the significant changes in LC and LDI during the 1st period (1950-1986) was concentrated in a relatively short 7-year final period after 1979 when the collectivization process began. The process of migration from hamlets to the core part began already before 1980, while the total population of the municipality did not decrease (Matrika Hrušov). In 1989, shortly after 1986 which is a turning point between the monitored periods, another turning point 
occurred in the political and economic development of former Czechoslovakia - the end of socialism, advent of democracy and market economy with all positives and shortcomings, and the establishment of the independent Slovak Republic in 1992. Socialist collectivization model ended; part of the land was given back to the original owners. New farmers were facing the problems of fragmented and unclear land ownership which were not solved during the socialist era. On the other hand, the cultivation efficiency increased.

Out of three surrounding villages with a significant share of population in the hamlets (Čelovce, Opava, Sucháň), the LC changes in Opava were the most similar to those in Hrušov (decrease in the arable land and growth of forests in the period 1945-2016). In the other two villages during 1986-2016, the share of arable land and forests remained unchanged, while in Čelovce (the neighbouring municipality), the share of arable land even slightly increased which implies that LC changes across the municipalities in wider region (Krupinská planina) did not follow the same trend (Parcelné protokoly obcí, own calculations). The results of the study carried out by Petrovic in the west-central Slovakian dispersed settlement region show that in three local municipalities the share of arable land decreased from 18 to 10\% between 19562002 and the share of forests, including non-woody vegetation, increased from 49\% to $59 \%$ at the same time (Petrovič, 2006a). Though these data refer to a shorter reporting period, they are comparable with the trend in Hrušov. Similar to Hrušov a significant decrease in the share of arable land (by about 11\%), a slight increase in the share of forests (by about 6\%) and an unchanged extent of grasslands between 1950-2014 was reported in the region with dispersed settlements in Kysuce (northwest Slovakia) (Barančok \& Barančoková, 2016). The comparisons above indicate a similar trend but higher intensity of LC changes in the studied area compared to the related regions in Slovakia. The decreasing trend in the share of arable land and increase of forests can be considered dominant in the most of the former socialist countries (Baumann et al., 2011; Van Vliet et al., 2015; Kuemmerle et al., 2016; Munteanu et al., 2017; Janus \& Biozek, 2019).

Comparison of LC and LDI changes in the studied area and in other regions shows differences and delays in trends in Hrušov which are conditioned by the local specificities:

- settlement-demographic - double-residency model, by its genesis different from most of the dispersed settlement types in the near and distant surroundings;

- political, social and economic - marginal position towards Czechoslovak (Slovak) central regions, delayed and relatively short-term collectivization of agriculture, position on the ethnical Slovak-Hungarian divide, the confessional exclusivity of the local population towards the surrounding villages;

- physical-geographical - high proportion of flat plains in the highest parts of the area remoted from the core part, which have the most suitable conditions for agriculture.

From our findings it revealed that the presence of hamlets is the most serious determinant of LC and LDI changes. The character, dynamics and time distribution of LC and LDI changes are differentiated within the cadastre. For this reason, it is difficult to implement a single LC conversion scheme for the entire study area, especially when some LC conversion processes are not interpreted unambiguously, as Rounsevell et al. (2012) points out using the example of intensification of agriculture.

Hersperger and Bürgi (2009) reported that over the past 70 years the main drivers of $L C$ changes were economic drivers followed by political drivers. This is particularly wellfounded in the Western Europe where the model of market economy has been present and dominant for a long period and where LC changes have been the result of a gradual socio-economic transformation (Baumann et al., 2011). In Slovakia, as in the most former socialist countries, there were two major political breaks over the past 70 years with direct economic impacts - the transition from the market economy to the collectivized one 
after 1948, and the re-establishment of the market economy after 1989. In contrast to the Western Europe, the main driving force of LC changes here were the political changes.

LDI analysis shows that the highest LDI values are at the $\mathrm{HH}$ level (Fig. 6) (not considering the WA level). The LDI value in $\mathrm{HH}$ is increased partly also by the pattern of home-gardens and roads whose density is significantly higher than at the other levels assessed. The increase of LDI values in areas with dispersed settlement was confirmed on the Slovak level by Otahel', Feranec and Machková (2002). The values of LDI on individual levels correspond, in general, to the values of LDI in comparable area units calculated in Slovakia (Otahel' et al., 2004 - for the district Skalica; Štefunková \& Hanušin, 2019 - for three wine-growing areas) or at 56 test sites in Estonia (Palang et al., 1998).

\section{Conclusion}

Unlike most regions of dispersed settlements in Europe and Slovakia, the pattern of the dispersed settlement in Hrušov has been generated historically during a relatively short period of time which was one of the reasons why it is a specific type of dispersed settlement. The results show that LC changes in the study area essentially follow the overall trend of LC changes in most European countries, i.e. retreat of arable land and spread of forests. Concurrence of the local specifics caused that the obtained results differ in some aspects from the results obtained in other areas of dispersed settlement in Slovakia. Two of the hypotheses were confirmed, one was confirmed partially as its validity is rather related to a certain period, and one hypothesis was not confirmed. The concept of four levels of LC and LDI changes allowed us to identify the internal spatial differentiation of the landscape. The dynamics and timing of these changes vary from one level to another. $\mathrm{HH}$ shows the most significant LC and LDI changes compared to other areas. These conclusions confirmed our first two hypotheses. The hypothesis about dependence of the share of arable land and forests at the $\mathrm{HH}$ level on the distance from the core part and the selected morphometric parameters was partially confirmed. The hypothesis about the population number in hamlets as a determinant of LDI changes was not confirmed. It was shown that at the $\mathrm{HH}$ level the number of the patches had a more significant impact on the LDI value than the population number in hamlets. The setting of circles of equal size at the $\mathrm{HH}$ and $\mathrm{ALH}$ levels allowed a correct comparison of the nature and changes of LC and LDI in the dispersed settlement and agricultural land. This revealed a different, autonomous development of LC and LDI at the $\mathrm{HH}$ level and thus confirmed the main hypothesis of the study about dispersed settlements being the main differentiating factor of the LC and LDI values.

The study contributes to dissemination of knowledge of the dispersed settlement landscape which is a traditional and important part of the settlement system in many countries and is one of the types of a historical settlement in cultural landscape. The maintenance of a functional dispersed settlement in the studied region depends on the search for compromises between traditional and modern agriculture based on the principles of sustainable development and on the protection of the remnants of the traditional agricultural and residential landscape.

\section{Acknowledgement}

This paper was prepared within the project of the Scientific Grant Agency of the Ministry of Education, Science, Research and Sport of the Slovak Republic and the Slovak Academy of Sciences VEGA No. 2/0013/18 Evaluation of the transformation of natural and socio-cultural diversity of the cultural landscape in Slovakia (on example of selected areas).

\section{Editors' note:}

Unless otherwise stated, the sources of tables and figures are the authors', on the basis of their own research. 


\section{References}

Amate, J.I., Villa, I., Jimenéz, F., De Molina, M.G. (2016). The rise and fall of the cortijo system: scattered rural settlements and the colonization of land in Spain's Mediterranean mountains since 1581. Journal of Historical Geography, 54, 63-75. https://doi.org/10.1016/j.jhg.2016.09.001

Barančok, P., Barančoková, M. (2016). Historical changes in dispersed kopanitse land type and changes in use of agricultural land on Kysuce region example. Ekológia (Bratislava), 35(4), 371-391. https://doi.org/10.1515/eko-2016-0030

Baumann, M., Kuemmerle, T., Elbakidze, M., Ozdogana, M., Radeloff, V.C., Keuler, N.S., Prishchepov, A.V., Kruhlov, I., Hostert, P. (2011). Patterns and drivers of post-socialist farmland abandonment in Western Ukraine. Land Use Policy, 28, 552-562. https://doi.org/10.1016/j.landusepol.2010.11.003

Bernhard, S. (1931). Une Formule Pour La Cartographie De l'Habitat Rural Avec, Application Au Department De Youne. Comptes Rendu, 3, 108-117.

Bibby, P., Brindley, P. (2013). Urban and rural area definitions for policy purposes in England and Wales: Methodology (v1.0). Government Statistical office. [12 November 2019] https://assets.publishing. service.gov.uk/government/uploads/system/uploads/attachment_data/file/239477/RUC11methodologypaperaug_28_Aug.pdf

Birch, B.P. (1967). The Measurement of Dispersed patterns of Settlement. Tijdschrift voor Economische en Sociale Geografie, 58, 68-75. https://doi.org/10.1111/j.1467-9663.1967.tb01065.x

Bodzak, D., Kiełczewska-Zaleska, M. (1973-1977). Wiejskie osadnictwo rozproszone, In Narodowy Atlas Polski, plate 61, 1:2,000,000. Warszawa: Ossolineum.

Botík, J. (1980). Dvojrezidenčnost' ako dôsledok lazového osídlenia. Slovenský národopis, 28(1), 78-83.

Brada, P., Zrníková, K., Brloš, J. (2014). Rolníctvo v Hrušove. Hrušov: Obecný úrad.

Brown, M.T., Vivas, M.B. (2005). Landscape development intensity index. Environmental Monitoring and Assessment, 101, 289-309. https://doi.org/10.1007/s10661-005-0296-6

Černe, A. (2004). Dispersed and decentralised settlement system. Dela, 21, 83-95.

Deffontaines, P. (1931). Un type de peuplement dispersé en Slovaquie. In Príspevky k praveku, dejinám a národopisu Slovenska. Sborník archeologického a národopisného odboru Slovenského vlastivedného múzea za rok 1924-1931 (pp. 90-96). Bratislava: Nákladom spoločnosti Slovenského vlastivedného múzea.

Demangeon, A. (1933). Une carte del Habitat. Annales de Geographie, 42, 225-232.

Dovring, F. (1965). Agricultural settlement and the layout of land. In Land and labor in Europe in the twentieth century (pp.10-56). Studies in social life. Dordrecht: Springer. https://doi.org/10.1007/978-94-017-6525-1_2

Druga, M., Faltan, V. (2014). Influences of environmental drivers on land cover structure and its long-term changes: A case study of the villages of Malachov and Podkonice in Slovakia. Moravian Geographical Reports, 22(3), 29-41. https://doi.org/ 10.2478/mgr-2014-0016

Environmental Protection Agency, Ireland (EPA). (2008). State of Environment. Report 2008. Chapter Land use, (pp. 158-171). [9 October 2019] https://www.epa.ie/pubs/reports/indicators/irlenv/43366\%20 EPA\%20report\%20chap\%20111.pdf

Fekete, Š. (1947). Typy vidieckeho osídlenia na Slovensku. Spisy Slovenskej zemepisnej spoločnosti, 1, 7-17.

Feranec, J., Šúri, M., Cebecauer, T., Otahel', J. (2002). Methodological aspects of landscape changes detection and analysis in Slovakia applying the CORINE land cover databases.

Geografický časopis, 54(3), 271-288.

https://www.sav.sk/index.php?lang=sk\&doc=journal-list\&part=article_response_page\&journal_article_no=7448

Feranec,J., Jaffrain, G., Soukup, T., Hazeu, G. (2010). Determining changes and flows in European landscapes 1990-2000 using CORINE land cover data. Applied Geography, 30(1), 19-35. https://doi.org/10.1016/j.apgeog.2009.07.003 
Fletcher, R. (2019). Trajectories to low-density settlements past and present: Paradox and outcomes. Frontiers in Digital Humanities. https://doi.org/10.3389/fdigh.2019.00014

Frolec,V. (1980). „Kolibarská“ sídla ve východní části Balkánskeho polostrova. Slovenský národopis, 28(1), 64-67.

Gibas, P., Heffner, K. (2018). Koncentracja zabudowy na obszarach wiejskich. Wieś i Rolnictwo, 179(2), 189-207. https://doi.org/10.7366/wir022018/10

Google Earth Pro. 8.7. (2016). Hrušov, Slovakia, 4809'15.01"N, 1905'28.58"E, eye altitude 7000 m.

Hanušin, J., Lacika, J. (2017). Vybrané environmentálne súvislosti zmien historickej lazníckej krajiny (na príklade obce Hrušov, okres Vel'ký Krtíš). Geografický časopis, 70(1), 57-77.

https://doi.org/10.31577/geogrcas.2018.70.1.04

Hanušin, J., Lacika, J. (2018). Transformácia historickej kultúrnej krajiny s rozptýleným osídlením (na príklade obce Hrušov, okres Vel'ký Krtíš). In V. Ira, J. Hanušin (Eds.), Geographia Slovaca, 33, Premeny a ochrana historickej kultúrnej krajiny na Slovensku (pp. 85-120). Bratislava: Geografický ústav SAV. [17 September 2019] https://www.sav.sk/journals/uploads/11081048GS_33.pdf

Havlíček, M., Skokanová, H., Dostál, I., Vymazalová, M., Pavelková, R., Petrovič, F. (2018). The consequences of establishing military training areas for land use development - A case study of Libavá, Czech Republic. Land Use Policy, 73, 84-94. https://doi.org/ 10.1016/j.landusepol.2018.01.039

Hersperger, A.M., Bürgi, M. (2009). Going beyond landscape change description: Quantifying the importance of driving forces of landscape change in a Central Europe. Case study. Land Use Policy, 26, 640-648. https://doi.org/10.1016/j.landusepol.2008.08.015

Historická ortofotomapa @ GEODIS SLOVAKIA, s.r.o., Historické LMS @ Topografický ústav Banská Bystrica, Ortofotomapa @ EUROSENSE, s.r.o. a GEODIS SLOVAKIA, s.r.o., mapové podklady @ Topografický ústav Banská Bystrica, (C TU Zvolen (2017).

Hočevar, M. (2012). Dispersed settlement in detached houses: Attitudes over the residential space consumption in Slovenia. Sociologija, 54(1), 123-152. https://doi.org/10.2298/SOC1201123H

Horváth, P. (1980). Historický prehl'ad vzniku a rozvoja chotárnych sídiel v slovenskej časti Karpát. Slovenský národopis, 28(1), 8-18.

Hromádka, J. (1943). Všeobecný zemepis Slovenska. Bratislava: Slovenská akadémia vied a umení.

Huba, M. (1989). O niektorých otázkach genézy a súčasného stavu kopaničiarskeho osídlenia na území Slovenskej socialistickej republiky. Geografický časopis, 41(2), 138-155.

Huba, M. (1990). O perspektívach kopaničiarskeho osídlenia a kopaničiarskej krajiny na území Slovenskej republiky. Geografický časopis, 42(2), 113-130.

Huba, M. (1997). Kopaničiarske osídlenie, životné prostredie a trvalo udržatel'ný spôsob existencie. Životné prostredie, 31(2), 61-66.

Hudson, J.C. (1969). A location theory for rural settlement. Annals of the Association of American Geographers, 59(2), 365-381. https://doi.org/10.1111/j.1467-8306.1969.tb00676.x

Janšák, Š. (1929). Príspevok k štúdiu osídlenia Slovenska. Obce a kopanice. Sborník muzeálnej slovenskej spoločnosti, 23(3-4), 93-111.

Janus, J., Bozek, P. (2019). Land abandonment in Poland after the collapse of socialism: Over a quarter of a century of increasing tree cover on agricultural land. Ecological Engineering, 138(31),106-117. https://doi.org/10.1016/j.ecoleng.2019.06.017

Kiełczewska-Zaleska, M. (1970). Rozmieszczenie wiejskich osiedli rozproszonych w Polsce. Przeglad Geograficzny, 42(2), 225-234.

Kolektív. (1990). ÚPN - Z. Hrušov, laznícke osídlenie. Sprievodná správa. Banská Bystrica: Stavoprojekt, š. p. Ateliér 4.

Kovács, A.D., Farkas, J.Z. (2011). Problems and development concepts for scattered farms in Hungary - A case study from the "Kiskunság region". Hrvatski geografski glasnik, 73(2), 165-177.

https://doi.org/10.21861/HGG.2011.73.02.12 
Krajewski, P. (2015). Landscape changes in selected suburban areas of Bratislava (Slovakia), In L. Halada, A. Bača, M. Boltižiar (Eds.), Landscape and Landscape Ecology - proceedings of the 17th International Symposium on Landscape Ecology (p. 110), Bratislava: Institute of Landscape Ecology, Slovak Academy of Sciences.

Kuemmerle, T., Levers, C., Erb, K., Estel, S., Jepsen, M.R., Mueller, D., ... Reenberg, A. (2016). Hot spots of land use change in Europe. Environmental research letters, 11(6), 1-14. https://doi.org/10.1088/1748-9326/11/6/064020

Kupková, L. (2001). Land use as an indicator of the anthropogenic impact on the landscape Land use/ land cover changes in the period of globalisation. In I. Bičík, et al. (Eds.), Land Use/Land Cover Changes in the Period of Globalization. Proceedings of the IGU-LUCC International Conference Prague (pp. 133-143). Praha: Karlova univerzita.

Lake, J., Edward, B., Bannister, N. (2014). Farmsteads and Landscapes in Kent. Archaeologia Cantiana, 134, 105-139. https://www.kentarchaeology.org.uk/Research/Pub/ArchCant/134-2014/134-04.pdf

Lapin, M., Faško, P., Melo, M., Štastný, P., Tomlain, J. (2002). Klimatické oblasti. Mapa 1: 200,000. Atlas krajiny Slovenskej republiky. Bratislava: Ministerstvo životného prostredia Slovenskej republiky, Esprit, s.r.o.

Lauko, V. (1985). Vývoj a transformácia kopaničiarskeho osídlenia Myjavskej pahorkatiny. Acta Facultatis Rerum Naturalium Universitalis Comenianae, Geographica, 25, 35-52.

Lőw, J., Míchal, I. (2003). Krajinný ráz. Kostelec nad Černými lesy: Lesnická práce.

Lukniš, M. (1980). Kopaničiarske osídlenie v Gemeri. Slovenský národopis, 28(1), 41-50.

Maglocký, Š. (2002). Potenciálna prirodzená vegetácia. Mapa 1: 500,000. Atlas krajiny Slovenskej republiky. Bratislava: Ministerstvo životného prostredia Slovenskej republiky, Esprit, s.r.o.

Matrika obce Hrušov. (Hrušov Parish register, handwriting). Hrušov: Obecný úrad.

Mandal, R.B. (1988). Systems of rural settlements in developing countries. New Delhi: Concept Publishing Company.

Martinka, J. (1927). Morfologické typy slovenských osád. Sborník muzeálnej slovenskej spoločnosti, 21(1), 48-57.

Matsumoto, T. (1950). Structure of dispersed settlement and its history the Nagaoka plateau, Kochi prefecture. Japanese Journal of Human Geography, 2(1), 24-38. https://doi.org/10.4200/jjhg1948.2.24

Mazúr, E., Luknišs, M. (1978). Regionálne geomorfologické členenie SSR. Geografický časopis, 30(2), 101-125.

Measuring Dispersion of Rural Settlements. http://www.access.arch.cam.ac.uk/schools/hefa/report

Mésároš, J. (1966). K dejinám kopaníc a kopaničiarskeho osídlenia na Slovensku. Vlastivedný časopis (Pamiatky a múzeá), 15(4), 173-179.

Míchal, I. (1982). Principy krajinářského hodnocení území. Architektúra a urbanizmus, 16(Z), 65-87.

Miklós, L. (1986). Stabilita krajiny v ekologickom genereli SSR. Životné prostredie, 20(2), 87-93.

Munteanu, C., Radeloff, V., Griffiths, P., Halada, L., Kaim, D., Knorn, D. et al. (2017). Land change in the Carpathian region before and after major institutional changes. In G. Gutman, V. Radeloff (Eds.), Landcover and land-use changes in eastern Europe after the collapse of the Soviet union in 1991 (pp. 57-90). Cham: Springer International Publishing. https://doi.org/10.1007/978-3-319-42638-9_4

Národný archív SR. Sčitanie ludu k 1. marcu 1950. (Census, 1 March 1950). Zložka Hrušov okres Šahy.

Okamoto, K. (1955). Dispersed settlement and its relation to the surface configuration on the deltaic plain of Kanto. Japanese Journal of Human Geography, 7(3), 182-194.

https://doi.org/10.4200/jjhg1948.7.182

Omasta, Š. (2010). K niektorým otázkam vyčleňovania území s rozptýleným osídlením: príklad Myjavskej kopaničiarskej podoblasti. Geographia Cassoviensis, 4(2), 141-146. [24 September 2019] https://geografia.science.upjs.sk/images/geographia_cassoviensis/ articles/GC-2010-4-2/00GC10_1a.pdf 
Omasta, Š. (2011). Rozptýlené vidiecke osídlenie - socioekonomické a historické aspekty. Životné prostredie, 45(1), 43-47. [24 September 2019]

http://publikacie.uke.sav.sk/sites/default/files/2011_1_043_047_omasta.pdf

Otahel', J., Feranec, J., Machková, N. (2002). Diverzita krajiny Slovenska. Geografický časopis, 54(2), 131-150.

Otahel', J., Feranec, J., Cebecauer, T., Pravda, J., Husár, K. (2004). Krajinná štruktúra okresu Skalica: hodnotenie zmien, diverzity a stability. Geographia Slovaca, 19. Bratislava: Geografický ústav SAV.

Owen, S., Sarlov-Herlin, I. (2009). A sustainable development framework for a landscape of dispersed historic settlement. Landscape research, 34(1), 33-54. https://doi.org/10.1080/01426390802448190

Palang, H., Mander, Ü., Luud, A. (1998). Landscape diversity changes in Estonia. Landscape and Urban Planning, 41, 163-169. https://doi.org/10.1016/S0169-2046(98)00055-3

Parcelné protokoly obcí Čel'ovce, Opava, Sucháň. Vel'ký Krtíš: Okresný úrad vo Vel'kom Krtíši, katastrálny odbor.

Pavlík, Z., Kühnl, K. (1981). Úvod do kvantitativních metod pro geografy. Praha: Universita Karlova, Fakulta prírodovědecká, SPN.

Pawlowski, S. (1938). Encare Une Methode De Representation Cartographiuqe Generale De I' Habtat Rural. Comptes Rendu, 2, 129-130.

Petrovič, F. (2006a). Vztáah rozptýleného osídlenia k morfometricko-polohovým vlastnostiam reliéfu. Acta Environmentalica Universitatis Comenianae (Bratislava), 14(1), 105-113. [9 September 2019] https://fns.uniba.sk/fileadmin/prif/actaenvi/ActaEnvi_2006_1/11_Petrovic.pdf

Petrovič, F. (2006b). The changes of the landscape with dispersed settlement. Ekológia (Bratislava). 25(Suppl. 1), 201-211. [9 September 2019] http://publikacie.uke.sav.sk/sites/default/files/EkSup10621petr_0.pdf

Prus, B., Bacior, S., Dudzinska, M. (2017). Settlement network concentration as determinant for rural areas development. In Proceedings of the 16th International Scientific Conference "Engineering for Rural Development", Jelgava, Latvia (pp. 474-480). https://doi.org/10.22616/ERDev2017.16.N093

Roberts, B.K. (1996). Landscapes of settlement. Prehistory to the present. London - New York: Routlege.

Roberts, B.K., Wrathmell, S. (2000). An atlas of rural settlement in England. (2003 Reprinted with corrections). London: English Heritage.

Rostankowski, P. (1982). Die Entwicklung osteuropäischer ländlicher Siedlungen und speziell der Chutor-Siedlungen (Vol. 117). Berlin: In Kommission bei Duncker \& Humblot.

Rounsevell, M.D.A., Pedroli, B., Erb, K.H., Gramberger, M., Busck, A.G., Haberl, H., ... Wolfslehner, B. (2012). Challenges for land system science. Land Use Policy, 29, 899-910. https://doi.org/10.1016/j.landusepol.2012.01.007

Salvati, L.,Munafo, M., Morelli, V.G., Sabbi, A. (2012). Low-density settlements and land use changes in a Mediterranean Urban Region. Landscape and Urban Planning, 105, 43-52. https://doi.org/10.1016/j.landurbplan.2011.11.020

Schulp, C.E., Levers, C., Kuemmerle, T., Tieskens, K.F., Verburg, P.H. (2019). Mapping and modelling past and future land use change in Europe's cultural landscapes. Land Use Policy, 80, 332-344. https://doi.org/10.1016/j.landusepol.2018.04.030

Schwartz, G. (1989). Algemeine Siedlungsgeographie: Teil 1: Die ländliche Siedlungen-Die zwischen Land und Stadt sthenden Siedlungen. Berlin - New York: Walter de Gruyter.

Skanes, H.M., Bunce, R.G.H (1997). Directions of landscape change (1741-1993) in Virestad, Sweden - characterised by multivariate analysis. Landscape and Urban Planning, 38, 61-75.

https://doi.org/10.1016/S0169-2046(97)00019-4

Śleszyński, P., Gibas, P., Sudra, P. (2020). The problem of mismatch between the CORINE Land Cover data classification and the development of settlement in Poland. Remote Sensing, 12.

https://doi.org/10.3390/rs12142253 
Spišiak, P. (1998). Vývoj obyvatel'stva v kopaničiarskom osídlení Slovenska. Geografické informácie, 5, $18-25$.

Stone, K.H. (1962). Swedish fringes of settlement. Annals of the Association of American Geographers, 52(4), 373-393. https://doi.org/10.1111/j.1467-8306.1962.tb00420.x

Stone, G.D. (1991). Agricultural territories in a dispersed settlement system. Current Anthropology, 32(3), 343-353. https://doi.org/10.1086/203967

Škrdlová, K. (2015). Program rozvoja obce Hrušov na roky 2015-2024. Vel'ký Krtíš: Centrum prvého kontaktu pre podnikatel'ov. http://www.hrusov.sk/download_file_f.php?id= 667070

Štatistický lexikón obcí Slovenskej republiky 1992: podla správného členenia k 30. júnu 1992 a výsledkov sčitánia ludu, domov a bytov k 3. marcu 1991. (1994). Bratislava: ŠEVT.

Štatistický lexikón obcí Slovenskej republiky 2011. (2014). Štatistický úrad Slovenskej republiky. https:/slovak.statistics.sk/wps/wcm/connect/cd33d897-7314-41d0-a12b-a95e537d7a39/Statisticky_lexikon_obci_Slovenskej_republiky_2011.pdf?MOD=AJPERES

Štefunková, D., Hanušin, J. (2019). Viticultural landscapes: Localised transformations over the past 150 years through an analysis of three case studies in Slovakia. Moravian Geographical Reports, 27(3), 115-168. https://doi.org/10.2478/mgr-2019-0012

Šúri, M. (2003). Vplyv reliéfu na diferenciáciu krajinnej pokrývky Slovenska. Geografický časopis, 55(1), 41-58. [17 June 2019] https://www.sav.sk/journals/uploads/05131244 Suri.pdf

Švecová, S. (1984). Lazy v 19. a 20. storočí. (Vývoj rol'níckych chotárnych sídiel v oblasti Krupinskej planiny). Praha: Univerzita Karlova.

Švecová, S. (1988). Lazy a lazníci. In J. Botík (Ed.), Hont-tradície ludovej kultúry (pp. 392-425). Martin: Osveta.

Takaki, M. (1958). Establishment and function of dispersed settlements. Japanese Journal of Human Geography, 10(4), 268-280. https://doi.org/10.4200/jjhg1948.10.268

Troha, A. (2017). Changing settlement patterns in areas of autochtonous dispersed settlement. Creativity Game - Theory and Practice of Spatial Planning, 5. Ljubljana: University of Ljubljana, Faculty of Architecture and Faculty of Civil and Geodetic Engineering. [14. November 2019] https://iu-cg.org/paper/2017/IU_CG_05-2017_troha.pdf

Urbieta, P., Fernandez, E., Ramos, L., Martínez, M.G., Bento, R. (2019). A land-cover based urban dispersion indicator suitable for highly dispersed, discontinuously artificialized territories: The case of continental Portugal. Land Use Policy, 85, 92-103. https://doi.org/10.1016/j.landusepol.2019.03.048

Van De Velde, L., Van Eetvelde, V., Antrop, M. (2010). A multistep method for historical characterisation of rural settlements in Belgium, results for the province of Antwerp. Proceedings of the Latvian academy of sciences, ser. A, 66(3), 93-104.

Van Vliet, J., De Groot, H.L.F., Rietveld, P., Verburg, P.H. (2015). Manifestations and underlying drivers of agricultural land use change in Europe. Landscape and Urban Planning, 133, 24-36.

https://doi.org/10.1016/j.landurbplan.2014.09.001

Verešík, J. (1974). Vidiecka sídla. In Slovensko: Ĺud 1. čast' (pp. 463-521), Bratislava: Obzor.

Zrníková, K., Hrčková, L. (2012). Výskum historických krajinných štruktúr a ich stupňa zachovalosti pre potreby starostlivosti o krajinu vo vybraných katastrálnych územiach Hriňová a Hrušov. Krajinno - ekologická štúdia. Zvolen: Technická univerzita vo Zvolene. 